\title{
Analysis of Factors Influencing the Student's Interests to Participate in Entrepreneurial Student Program
}

\author{
Hari Mulyadi, Eded Tarmedi, Gugun Ruslandi \\ Faculty of Economic and Business Education \\ Universitas Pendidikan Indonesia \\ harimulyadi@upi.edu
}

\begin{abstract}
Insufficient numbers of interest in entrepreneurial student program into a thing that cannot be ignored in the field of entrepreneurship. The main solution that must to do is investigating the factors that make students under interested towards entrepreneurial student program. This research aims to1) find the factors are influencing the students interests to participate the entrepreneurial student programing Indonesia university of education, 2) substantial influence off actors towards students interests to participate the entrepreneurial student programing Indonesia university of education. The type of the research is descriptive verification, and the method used are explanatory survey with simple random sampling technique with a sample of 86 respondents. Analysis technique of the data used are Kaiser-Meyer-Olkin Measure of Sampling Adequacy and simple linear regression analysis with software tools SPSS The results show that 1) The perception of the factors that influencing the interest consisting of Achievement Motivation, Attitude of Entrepreneurial, Perception of Entrepreneurship, Family Environment, Education and Training at the high category, 2) Factors of Education and Training is the most dominant variable or has the highest rating in influencing students' interest in participating the Student Entrepreneurial Program, while variable of Attitude of Entrepreneurial has the lowest rating, 3) Factors influencing the Student's Interests have influences with moderate correlation level of $54.31 \%$, while for the influence of other variables not researched approximately amounted to $45.69 \%$. This is indicating that if the higher the factors perception that influencing the interests therefore higher the interest of students to participate the Student Entrepreneurial Program.
\end{abstract}

Keywords- Achievement Motivation, Attitude of Entrepreneurial, Perception of Entrepreneurship, Family Environment, Education and Interests

\section{INTRODUCTION}

Entrepreneurship Profession in Indonesia, based on information from the Ministry of Manpower and Transmigration, it is still less attractive to the majority of the Indonesian people. It is listed with the number of people that entrepreneurship has been only reached 0.18 per cent of the 238 million population of Indonesia. Ideally, that Indonesia could be highly competitive requires at least 2 percent of the 238 million population of Indonesia, or about 4.76 million new entrepreneurs with diverse professions and expertise. [1]

The least number of Indonesian entrepreneurs are caused the lack of public interest for entrepreneurship, one of whom is a student. Student interest in entrepreneurship is low, from 4.8 million students, only 7.4 percent of students who are interested in entrepreneurship. This was stated by Advisor to the Minister of Cooperatives, Sutarto said that the low interest student entrepreneurship is also known from the data in the Ministry of Education and Culture which recorded 83.18 percent more college graduates interested in a worker or office employee. [2]

Based on this situation, universities in Indonesia which plays an important role to create the graduate students to be independent and able to create jobs after graduation. One of the factors driving the growth of entrepreneurship in a country are by the role of the university through the provision of education and entrepreneurship programs [3]. The university is responsible for educating and providing entrepreneurial skills for their graduates and provide motivation to dare choosing entrepreneurship as their career. The university needs to implement the entrepreneurial learning patterns based on empirical inputs to provide students with a significant knowledge in order to encourage students to be entrepreneurs [4]

Entrepreneurship interest is the best predictor for entrepreneurial behavior [5]. Therefore, the interest can be used as the basis of a reasonable approach to understand anyone who would become entrepreneurs [5]. Entrepreneurship interest to contribute significantly toward the entrepreneurial behavior of small traders [6].

Student Entrepreneurial Program is a priority program of Directorate General of Higher Education that the implementation was delegated to the universities for students who registered as an active student at each university, are intended to facilitate students entering the real business field through start-up business. Students (individual or group) who have an interest and entrepreneurial talent encouraged to start with science and technology base that is being studied. The number of applicants Student Entrepreneurial Program across Indonesia is still less and has not yet reached the target of about 13 percent of students throughout Indonesia. The role of government today is motivating students to socialize and Indonesia in order to follow this program through each University [8]

Similarly in Universitas Pendidikan Indonesia to socialize and motivate the students to participate in this program. Besides the problems the number of registrants Student 
Entrepreneurial Program continues to decline from year to year, it was also found data showing that the success rate of participants who run the business when it received funding.

Table 1. Shows that the number of successful participants of Student Entrepreneurial Program from 2012 to 2014 no more than $20 \%$. The success is measured by the interest of participants to continue their business when it was funded. It shows that lack of the entrepreneurial interest in Student Entrepreneurial Program.

TABLE I. STUDENT SUCCESS NUMBER OF ENTREPRENEURIAL STUDENT PROGRAM

\begin{tabular}{lllll}
\hline Year & $\begin{array}{c}\text { Amount of } \\
\text { Funded }\end{array}$ & $\begin{array}{c}\text { Amount of } \\
\text { Success }\end{array}$ & Percentage (\%) \\
2012 & 40 & 8 & 20 \\
2013 & 40 & 7 & 17,5 \\
2014 & 50 & 7 & 14 \\
\hline \multicolumn{4}{l}{ a. Reference: Directorate of UPI Student Affairs period 2012-2014 }
\end{tabular}

Participants of Regenerate the entrepreneurial interest is an important action because it will create an individual assessment that entrepreneurship is a need to overcome the obstacles encountered. Student's entrepreneurship is an independent person, who is able to manage a business for profit. In the face of various problems, students are required to be able to think creatively. They know how to achieve the planned objectives and are able to concentrate as well as the initiative to utilize the knowledge and experience to organize pace in accordance with plans made to achieve the target.

Entrepreneur is someone who has a desire of achieving very high compared with those who are not entrepreneurship. Achievement motivation (need for achievement): encouraging the individual achievement with the benchmark of achievement him self or others. One motive for entrepreneurship is important. Motivation also used to influence the entrepreneurial interest [9].

There was a lack of motives concerned with sustainable development of enterprise in a long run. On the other hand, there is a variety of different success factors affecting entrepreneurs, which primarily depend on the current situation in the local environment [10]

Finding the finding that achievement motivation, The Achieving Society influential, achievement motivation is very important for economic development and progress. Achievement motivation has been selected as the most common predictors of entrepreneurship. Several studies have found a positive relationship between achievement motivation and entrepreneurial behavior [11]

Research has been conducted that: Entrepreneurial education can affect students' attitudes toward entrepreneurship and their entrepreneurial self-efficacy. It also examines the role of family exposure to business, personal entrepreneurial experience, and ethnic background in affecting attitudes, subjective norms, and intentions by comparing students from diverse ethnic and family backgrounds. Findings highlight the impact of education and practical exposure to entrepreneurship on entrepreneurial intentions [12]
The most fundamental conclusion to this special issue, however, is that the link between education, training, intent and actual career choice to start up a business is a complex process and remains under-investigated. There is no universal approach to graduate enterprise/entrepreneurship that works for all contexts and graduates and different contexts require tailored approaches to best suit their individual needs [13]

Several factors that affect student the entrepreneurial interest are:

1) The internal factors are factors that are within oneself. The internal factors include: motivation, mental attitudes also perceptions

2) The external factors are factors that are beyond one's self. The external factors include: family environment also education and training. [14]

Those problems could be overcome by several factors such as achievement motivation, family environment, and entrepreneurship mental attitude, student perception of entrepreneurship, also education and training. Motivation influence has a significant influence on the entrepreneurial interest to participate Accounting Professional Education. This may be due to a boost in students to have and improve the quality and ability in the field of practiced, particularly in the field of accounting profession [15]. Among the intrinsic factors and intrinsic factors together provide a boost to the student interest in entrepreneurship are included in the high category, but the encouragement of the students' personality is dominant when compared with the encouragement of external students.[16]

The purpose of this study as below:

1) What factors are affecting the interests of students in participating the Student Entrepreneurial Program in Universitas Pendidikan Indonesia

2) What student interest description in participating the Student Entrepreneurial Program in Universitas Pendidikan Indonesia

3) what factor is dominant affecting the interests of students in participating the Student Entrepreneurial Program in Universitas Pendidikan Indonesia

\section{LITERATURE}

Entrepreneurship theory and research have been developed in several disciplines such as economics, management, business administration, sociology, psychology, anthropology, business history, strategy, marketing, finance and geography. The disciplines in the study of entrepreneurship is classified into six category theory of entrepreneurship, namely: economic entrepreneurship theory, psychology entrepreneurship theory, sociological entrepreneurship theory, anthropological entrepreneurship theory, opportunity-based entrepreneurship theory, and resource-based entrepreneurship theory. [17], [18]

Psychological entrepreneurship theory emphasizes the individual characteristics of the entrepreneurial aspects that affect the performance of the business conducted. Psychological aspect is one of the factors that greatly affect an 
individual in performing activities of entrepreneurship, and the large potential for success with regard to the psychology of a person in performing a job or activities. The psychological aspect of an entrepreneur dealing with individual personality theories described in personality consisting of three domains, namely 1) Trait, 2) Cognition, 3) Social constructionism [19]

The trait can be seen as a characteristic or quality that distinguishes and affect the individual. Trait is defined as the dimension of individual differences in the tendency to show the consistency of thoughts, feelings, and behavior.Cognition deals with all forms of individual recognition of the reality of subjective and relational where individual behavior is formed by the action based on the cognition that know or think of a situation in which the behavior occurs. Social Constructivism is a social process through which an individual actions and interactions continuously creating a reality that is owned and jointly experienced subjectively

Personality trait is a characteristic that often arise and describe the behavior of an individual. Basic personality trait level unchanged from late adolescence to adulthood. McCrae and Costa believes that during the period from age 18 to 30 years, people are in the process of adopting the trait stable configuration, the configuration of which remained stable after 30 years old [20].

Interest is persisting tendency to pay attention to and enjoy some activity or content. [21]. Intentions as a condition previously deliberate in making it a habit. That intention can be called a tendency to do something [22]. Intention entrepreneurship is the tendency started the business venture or new ventures [23]. Entrepreneurship intention focused on a person's tendency to start entrepreneurial activities in the future. [24]

Based on these opinions, it is the intention of entrepreneurship is a tendency to start a business

Several factors that affect student the entrepreneurial interest are:

1) The internal factors are factors that are within oneself. The internal factors include: motivation, mental attitudes also perceptions

2) The external factors are factors that are beyond one's self. The external factors include: family environment also education and training.[13]

Motivation encourage individuals to perform the behavior of an activity and contributes greatly to the performance of individuals in their work. Motivation is composed of three key construction purposes, namely: 1). Expectations, as the belief in one's ability to control, conduct, or complete a task is a big predictor of achievement, 2). Value, as goal orientation or cognitive representation of purpose and value of task assignments beliefs about the importance of the task, a person's interest in the task and one's ideas about the usefulness of the end of the task, and 3). Affective component, as a general sense of self and one's emotional reactions to the task that affects cognitive resources and performance.

Based on expert opinion, the motivation is a behavior that is in one's personal driving ability of individuals through certain activities in order to achieve a goal. Motivation is needed in activity, particularly in entrepreneurship in order to achieve its objectives can be realized. Motivation is the impulse of self-entrepreneurship students to achieve a goal as optimally as possible and as entrepreneurs who can create jobs. Finding the finding that achievement motivation, The Achieving Society influential, achievement motivation is very important for economic development and progress. Achievement motivation has been selected as the most common predictors of entrepreneurship. Several studies have found a positive relationship between achievement motivation and entrepreneurial behavior [10]

The family is the first social group of human life where they learn and express themselves as social human interaction in the relationship with the group. In the family, the social interaction based on sympathy for his family, a child first learn to pay attention to the wishes of others, learn to work together, helping each other, in other words, children first learn to play a role as social beings who have norms and specific skills in interactions with others [23]

Perception occurs because of the stimulus from the surrounding environment, so that individuals can give meaning interpret something. In the process of perception of the individual is required to provide an assessment of an object that can be either positive or negative, happy not happy, and so on. Perception viewpoint is the starting point of thought which is composed of words that are used to understand the incidence or symptoms of life [24]. Perception is a process that involves the inclusion of the message information into the human brain, through human perception in constant contact with the environment. This relationship is done through the senses, the senses of sight, hearing, touch, taste, and smell [25]

Entrepreneurial education designed to inculcate competencies, skills and values necessary to identify business opportunities, organize and start a new business [26]. Competencies acquired learners not only limited competence to sell goods or services such as the mindset of most people who consider entrepreneurship was limited as traders. Entrepreneurship education is to teach people to start new businesses successfully and operate the businesses profitably, and thus facilitates the economic growth" [27]

\section{RESEARCH METHODS}

As for the object of study as the dependent variable is interest and the independent variables are factors that influence to interest. The object of this research is the Student Entrepreneurial Program Participants spread across seven faculties in Unversitas Pendidikan Indonesia. This research was done in less than one year, then the method used is cross sectional method [28] the population in this research is the students who were participating in the Student Entrepreneurial Program in Universitas Pendidikan Indonesia by totaling 613 students. The sampling uses is Simple Random Sampling of the population and by using Solving Formula and choose 86 samples. 


\section{RESULTS AND DISCUSSION}

Analysis of factors affecting interest by Using Test of KaiserMeyer-Olkin Measure of Sampling Adequacy (KMO MSA)

This study has one hypothesis being tested, that there are factors that influence to the interest. Test carried out using SPSS. The results obtained show the relationship between a numbers of variables that are independent from one another. Results of statistical tests performed by Bartlett test of Spericity Test and Measure of Sampling Adequacy (MSA) to determine the relationship between a numbers of variables.

Table II show relationship factors that influence to the students interest for participating in the Entrepreneurial Student Program UPI. The results above showed that among variables have shown a significant correlation. It can be seen from the Bartlett's Test of Sphericity with Chi-Square score 2997.339 $(\mathrm{df}=666)$ with a score Sign <Alpha $10 \%(0.000<0.1)$. It shows the correlation matrix is not an identity matrix to allow for principal component analysis. In addition, the score of Kaiser-Meyer-Olkin Measure of Sampling Adequacy (KMO) showed the score of 0.754 where the score is greater than 0.1 so that the factor analysis model has been a significant correlation.

TABLE II KMO AND BARTLETT'S TEST

\begin{tabular}{|c|c|c|}
\hline \multicolumn{2}{|c|}{ Kaiser-Meyer-Olkin Measure of Sampling Adequacy. } &, 754 \\
\hline \multirow{3}{*}{ Bartlett's Test of Sphericity } & Approx. Chi-Square & 2997,339 \\
\hline & Df & 666 \\
\hline & Sig. & 000 \\
\hline
\end{tabular}

Factor analysis is an analytical process that uses scales of measurement. On the Anti-Image Correlation shows MSA score of each variable studied. MSA score of more than>0.51.0 indicate that these variables indicate the factor analysis has been done partially right. The results showed that of the 37 variables ( 5 factors ) tested the score of all the variables MSA> 0.5-1.0 with, 877a as the greatest score of the variable Education and training is the ability level of the participants in capturing the material presented and 525a as the smallest score Perception of Entrepreneurship is variable rate needs must always be realized. It can be concluded that the factors analyzed are correct.

\section{Simple Linear Regression Analysis}

Based on the results of the processing performed, the output obtained from the calculation of Pearson product moment correlation coefficient as below.

Table III explains that the correlation between the 5 factors (X) to interest $(\mathrm{Y})$ is equal to 0.737 because it is the interpretation of the correlation coefficient (.60 to .799) means that there is a strong relationship between the interest factors. P-score in the column sig. (1-tailed) $0.000<0.1$ level of significant $(\alpha)$, which means that the factors correlated with interest.

\section{TABLE III OUTPUT OF CORRELATION COEFFICIENT}

\begin{tabular}{rrrr}
\hline & & \multicolumn{1}{l}{ Interest } & \multicolumn{2}{l}{ Factors } \\
& & & \\
\hline \multirow{2}{*}{ Pearson Correlation } & Interest & 1,000 &, 737 \\
\cline { 2 - 5 } & Factors &, 737 & 1,000 \\
\hline \multirow{2}{*}{ Sig. (1-tailed) } & Interest &. &, 000 \\
\cline { 2 - 5 } & Factors &, 000 & 86 \\
& Interest & 86 & 86 \\
\cline { 2 - 4 } & Factors & 86 & c. Reference: 2015 of data processing. \\
& & d. Reference: Sugiyono (2013: 247)
\end{tabular}

Table IV model of summary output SPSS, it can be seen that the correlation or relationship between factors of interest to obtain a yield of 0.737 (positive). In accordance with the guidelines to provide interpretation of the correlation coefficient [29], the correlation between the factors included into the category of the strong interest in being on the interpretation of the correlation coefficient $(0.60$ to 0.799$)$ by Standard Error of Estimate by 7,55880.

\section{TABLE IV OUTPUT OF MODEL SUMMARY}

\begin{tabular}{|c|c|c|c|c|}
\hline $\begin{array}{l}\text { Mode } \\
1\end{array}$ & $\mathrm{R}$ & $\begin{array}{l}\text { R } \\
\text { Square }\end{array}$ & $\begin{array}{l}\text { Acjusted R } \\
\text { Square }\end{array}$ & $\begin{array}{l}\text { Std Error of } \\
\text { the Estimate }\end{array}$ \\
\hline 1 & $.737^{7}$ & 543 & .537 & 3,85675 \\
\hline
\end{tabular}

\section{Simple Linear Regression Equation}

Simple Linear Regression Equation model that will be established in this study as below.

$$
\mathrm{Y}=\mathrm{a}+\mathrm{bX}
$$

Description:

$\mathrm{Y}=$ the dependent variable (Interests)

$\mathrm{X}=$ The independent variables (factors)

$\mathrm{a}=$ price of $\mathrm{Y}$ when $\mathrm{X}=0$ (constant prices)

$\mathrm{b}=$ number that affects an increase or decrease $\mathrm{Y}$ based on $\mathrm{X}$ (Factors)

Table $\mathrm{V}$ in column $\mathrm{B}$, listed a constant score and the score of a simple linear regression coefficients for the variables. Based on these scores then can be determined by simple linear regression model that is expressed in the following equation:

$$
\mathrm{Y}=\mathrm{a}+\mathrm{bX}
$$

$$
\mathrm{Y}=15.493+0,309 \mathrm{X}
$$

Based on simple linear regression equation above, a constant score of 15.493 states that if there are no factors, the amount of interest amounted to 15.493 . The regression 
coefficient on the variable factors is 0.309 which means that the unit score of each of the addition of the score factors will increase the interest of 0.309 unit score and if a decline in interest, these factors will reduce the interest amounting to 0.309 of the unit score.

TABLE V SIMPLE LINEAR REGRESSION MODEL

Coefficients $^{\mathrm{a}}$

\begin{tabular}{|c|c|c|c|c|c|c|}
\hline \multirow{2}{*}{\multicolumn{2}{|c|}{ Model }} & \multicolumn{2}{|c|}{$\begin{array}{l}\text { Unstandardized } \\
\text { Coefficients }\end{array}$} & \multirow{2}{*}{$\begin{array}{c}\text { Standardized } \\
\text { Coefficients } \\
\text { Beta }\end{array}$} & \multirow[t]{2}{*}{$\mathbf{t}$} & \multirow[t]{2}{*}{ Sig. } \\
\hline & & B & Std. Error & & & \\
\hline \multirow{2}{*}{1} & (Constant) & 15,493 & 3,235 & & 4,789 & ,000 \\
\hline & Factors & ,309 & ,031 & ,737 & 9,988 & ,000 \\
\hline
\end{tabular}

\section{Hypothesis Test}

To test the significance of the factors that influence to the interests can be used by $\mathrm{F}$ test, is by comparing the calculated $\mathrm{F}$ and $\mathrm{F}$ table. Formula F-test or ANOVA test.

Table VI shows testing for the F test taken from ANOVA with a level of probability ( $\mathrm{Sig})=0.000$, the significance level of 0.1 is $0,000 \unlhd), 1$. Then the decision is Ho rejected. This means that there is a positive influence of the factors that influence to the interests of an effect on the participants' interests the Student Entrepreneurial Program UPI.

Researchers also tested the effect of independent variables together on the dependent variable using the F test is F count> $\mathrm{F}$ table. Then $\mathrm{F}$ table with 86 respondents, on $=0.1$ is 2.719 . Thus obtained 99.750> 2.719, then Ho is rejected. In conclusion together with the tests performed by using a probability score. It can be concluded that the hypothesis in this study is Ho rejected and Ha accepted, so there is influence between Factors that influence to the interests of the participants' interests the Student Entrepreneurial Program UPI

\section{TABLE VI SIGNIFICANCE SCORE OF F TEST}

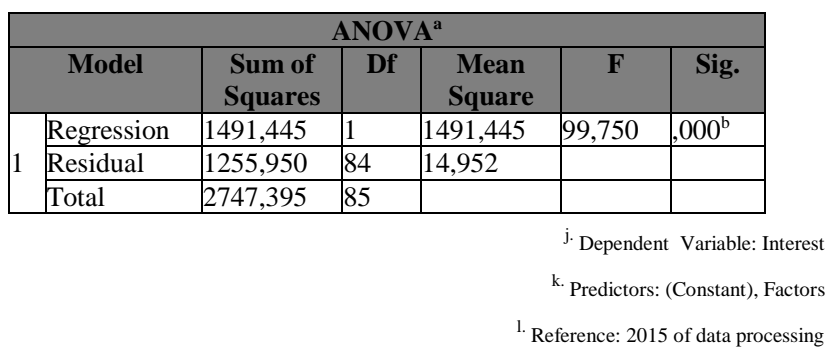

\section{Determination Coefficient Analysis}

To determine the percentage effect of $\mathrm{X}$ to $\mathrm{Y}$, then use the formula coefficient determination as below:

$$
\mathrm{KD}=\mathrm{r}^{2} \times 100 \%
$$

Description:

$\mathrm{r} 2=$ correlation coefficient $(\mathrm{R}$ square)

Here are the results of the calculation of the coefficient of determination from $\mathrm{X}$ to $\mathrm{Y}$ :

$$
\begin{aligned}
\mathrm{KD} & =\mathrm{r} 2 \times 100 \% \\
& =\mathrm{r} 2 \times 100 \% \\
& =(0.737) 2 \times 100 \% \\
& =0,543 \times 100 \% \\
& =54.31 \%
\end{aligned}
$$

From the results of the calculation of the coefficient of determination for the factors that influence to interest $(\mathrm{X})$ the interest $(\mathrm{Y})$ is $54.31 \%$ or that means the interest of $54.31 \%$ is influenced by factors that influence to interest while $45.69 \%$ influenced by other factors outside the factors explained.

From 5 factors above, the highest score is training and education factor is $78,63 \%$ and it's in high category. This is indicate that the all participants of student entrepreneurial program UPI are very interesting toward education and training held on committee of student entrepreneurial program are really good. From this entrepreneurial program, students are expected to move their interest after coached by this program. Education and training of entrepreneur is an improving of human resources is not only getting the knowledge, but also expected to change toward skills that they have and can be shared with other people in order to create the business to be better future in their life though experiences that there have.[30]

\section{CONCLUSIONS AND RECOMMENDATIONS}

\section{A. Conclusions}

1) The description of the factors that affect interest shows that these factors are comprised of Achievement Motivation, Attitude of Entrepreneurship, Entrepreneurial Perception, Family Environment also Education and training can influence the interests of students to participate the Student Entrepreneurial Program.

2) The description of the perception of the factors that influence to interest with the correlation level being at $54.31 \%$, while for the influence of other variables not studied amounted to $45.69 \%$. This shows that the higher the perception of the factors that influence to the interests of more higher the interest of students to participate the Student Entrepreneurial Program.

3) The description of the factor analysis toward 5 factors indicate that Education and Training factor is the most dominant or which has the highest score in influencing to the interest, while the entrepreneurial mental attitude has the lowest ratings in influencing to the interest.

\section{B. Recommendations}

1) Perception of the factors that influence to the interest of students to participate the Student Entrepreneurial Program UPI as a whole are the determining factors can influence to 
the interest. But there are some corrections that need to be made towards improving the mental attitude of students to do entrepreneurship, especially in the formation of mentalities and a sense of confidence in students so that they are able independently to entrepreneurship. Expected for any future efforts to increase interest in entrepreneurship in UPI can further provide flexibility and support students who want to start a business.

2) The results of the factor analysis stated to 5 variables showed that the factors of Education and Training is the most dominant factor who have the highest ratings in influencing, while the mental attitude of Entrepreneurship has the lowest ratings in influencing the interest. However, it should be maintained and even enhanced, especially in shaping the mental attitude and strong confidence in themself every UPI's student so that will be formed even higher.

3) The results stated perceptions of the factors that influence to the interests is positive and significant effect on the interest. Although it has been reached between medium and high category, but it still needs to be improved further. Because of all factors which consist of Achievement Motivation, Entrepreneurship Mental Attitude, Perception of Entrepreneurship, Family Environmental also Education and training are still under ideal score so that it can reach a higher level again.

4) As the material for further research of Student Entrepreneurial Program UPI, the researchers were able to lift some of the shortcomings issues regarding innovation factors that influence, are achievement motivation, Entrepreneurship mental attitude, perception of entrepreneurship, family environment also education and training of the Student Entrepreneurial Program participants UPI.

\section{REFERENCES}

[1] www.okezone.com, accessible Tuesday, March 3, 2015

[2] www.lensaindonesia.com/2012/02/21/minat-wirausaha-mahasiswarendah.html, accessed Friday, March 5, 2015

[3] Zimmerer Thomas W., Norman M. Scarborough. 2008. Essensial of Entrepreneurship and Small Business Management: alih bahasa. Jakarta: Salemba Empat.

[4] Lieli Suharti dan Hani Sirine. 2011. Faktor-faktor Yang Berpengaruh terhadap Niat Kewirausahaan Mahasiswa (Entrepreneurial Intention) Studi terhadap Mahasiswa UKSW Salatiga. Jurnal Manajemen dan Kewirausahaan. ISSN No : 1411-1438. Terakreditasi. Vol 13 No 2 Tahun 2011. Fakultas Ekonomi - Universitas Kristen Petra Surabaya.

[5] Indarti, N. dan Rostiani, N. 2008, Intensi Kewirausahaan Mahasiswa: Studi Perbandingan Antara Indonesia, Jepang dan Norwegia. Jurnal Ekonomika dan Bisnis Indonesia, Vol. 23, No. 4, Oktober

[6] Tony Wijaya.(2008)..Hubungan Adversity Intelligence dengan Intensi Berwirausaha Terhadap Siswa SMKN 7 Yogyakarta. Jurnal Manajemen dan Kewirausahaan, vol.9, no. 2, september 2007: 117-127.

[7] www.dikti.go.id, accessible Fidday, March 5,2015

[8] Buchari, Alma.(2013)..Kewirausahaan. Bandung: Alfabeta.
[9] Christopher J. Collins. (2004). The Relationship of Achievement Motivation to Entrepreneurial Behavior: A Meta-Analysis. from Cornell University, ILR School

[10] Emmeline de Pillis and Kathleen K. Reardon. The influence of personality traits and persuasive messages on entrepreneurial intention A cross-cultural comparison. Career Development International Vol. 12 No. 4, 2007

[11] Basu (2008). Entrepreneurial Intentions Amongst Students: A Comparative Study. Journal of 12th Annual Meeting of the National Collegiate

[12] Ghulam Nabi, Rick Holden, (2008) "Graduate entrepreneurship: intentions, education and training", Education and Training, Vol. 50 Iss: 7, pp. $545-551$

[13] Segal, G, D. Borgia dan J. Schoenfeld. 2005. The Motivation to Become An Entrepreneur. Journal of Entrepreneurial Behaviour and Reseach, Vol. 11, No.1 (42-57).

[14] Ellya Benny, Yuskar. 2006. Pengaruh Motivasi Terhadap Minat Mahasiswa Akuntansi Untuk Mengikuti Pendidikan Profesi Akuntansi (PPak) (Studi Empiris Pada Perguruan Tinggi Di Padang). Jurnal dan Prosiding SNA - Simposium Nasional Akuntansi

[15] Suryaman, Maman. (2006) Minat Berwirausaha Pada Mahasiswa Pendidikan Teknik Elektro Fakultas Teknik Universitas Negeri Semarang, Skripsi, Fakultas Teknik - Universitas Negeri Semarang.

[16] Simpeh, Kwabena Nkansah.(2011).Entrepreneurship Theories and Emperical Research: A Summary Review of The Literature. European Journal of Business and Management. ISSN 2222-1905(Paper) ISSN 2222-2839(Online), Vol 3, No.6, Hal 1-8

[17] Amolo, J dan S. O. Migiro.(2014).Entrepreneurship complexity: Salient Features of Entreprenuership. African Journal of Business Management. Vol. 8 (19), pp 832-841, Oktober 2014.

[18] Chell, Elizabeth. (2008).The Entrepreneurial Personality (A Social Construction) Seconf Edition. London: Routledge

[19] Feist, 2010: 121 in W. Edward McMullan, Thomas P. Kenworthy. Creativity and Entrepreneurial Performance: A General Scientific Theory.

[20] Krueger,N.F,2005, Handbook of Entrepreneurship Research: An Interdisciplinary Survey and Intrroduction. Springer

[21] Pillis, E. Reardon, K.K, 2007, The Influence Of Personality Traits And Persuasive Massages On Entrepreneurial Intention: A Cross-Cultural Comparison. Career Development International, 12(4):382-396

[22] Davidson, P. 1995, Determinant of Entrepreneurial Intentions. In Procceding Rent XI Workshop, Piacenza, Italy. http://eprint.qut.edu.au/archive/00002076/Retrived on Sept.2007

[23] Sobur Alex, 2011. Psikologi Umum, Bandung: Pustaka Setia.

[24] Ridwan Effendi \& Elly Malihah, 2007: 55. Pendidikan lingkungan sosial budaya dan teknologi. Yasindo Multi Aspek, Bandung.

[25] Slameto.(2010).Belajar dan Faktor-Faktor yang Mempengaruhinya. Jakarta: Rineka Cipta

[26] Prince Famous Izedonmi and Chinonye Okafor (2010), "The effect of Entrepreneurship Education on Students' Entrepreneurial Intentions", Global Journal of Management and Business Research, (Vol. 10 Issue 6 (Ver. 1.0) August 2010), pp.49-60.

[27] Lo. Choi Tung (2011: 36). ]The influence of theory of planned behavior and entrepreneurship.

[28] Malhotra, Naresh K.(2009). Riset Pemasaran Pendekatan Terapan Jilid 1. Jakarta:PT Index.

[29] Sugiyono. (2013). Metode Penelitian Kuantitatif, Kualitatif dan R\&D. Bandung: Alfabeta.

[30] Hari Mulyadi, (2011), Pengaruh Diklat, Magang Terhadap Sikap dan Motivasi Kewirausahaan Impliksinya Terhadap Perilaku Kewirausahaan, Disertasi 